\title{
PEMODELAN TARIKAN PERJALANAN ANGKUTAN BARANG DI PROVINSI KALIMANTAN TIMUR
}

\author{
Triana Sharly P. Arifin \\ Fakultas Teknik \\ Universitas Mulawarman \\ Jln. Sambaliung No. 9, Samarinda \\ triana.sharly@gmail.com
}

\begin{abstract}
East Kalimantan is a province with a large area in Indonesia. This causes the transportation of goods in the province is also large. The pattern of movement of goods in East Kalimantan Province is influenced by the potential of its natural resources. This study aims to analyze the attraction model of the movement of freight transportation in East Kalimantan Province, using the Origin and Destination Matrix of movement for 9 districts/cities in East Kalimantan Province, as well as the movement of 3 external zones. Furthermore the Origin and Destination Matrix of the movement is converted to trip units/year based on the type of truck most often used to transport goods. This is done so that in the analysis process, variables can be correlated with socio-economic data as independent variables. The analysis was performed using a zone-based correlation model, a step-by-step method of type 1. The results show that the best model for the attraction of freight transportation in East Kalimantan Province is a model that uses independent variables of egg production and chicken livestock, with a coefficient of determination of 0.564 .
\end{abstract}

Keywords: trip attraction,freight transportation, Origin and Destination Matrix, external zone

\begin{abstract}
Abstrak
Kalimantan Timur merupakan suatu provinsi dengan luas wilayah yang besar di Indonesia. Hal ini menyebabkan angkutan barang di provinsi ini besar pula. Pola pergerakan barang di Provinsi Kalimantan Timur dipengaruhi oleh potensi sumber daya alam yang dimilikinya. Studi ini bertujuan untuk menganalisis model tarikan pergerakan angkutan barang di Provinsi Kalimantan Timur, dengan menggunakan Matriks Asal Tujuan pergerakan untuk 9 kabupaten/kota di Provinsi Kalimantan Timur, serta pergerakan 3 zona eksternal. Selanjutnya Matriks Asal Tujuan pergerakan dikonversikan ke satuan trip/tahun berdasarkan jenis truk yang paling sering digunakan untuk mengangkut barang. Hal ini dilakukan agar dalam proses analisis, variabel dapat dikorelasikan dengan data sosial-ekonomi sebagai variabel bebas. Analisis dilakukan dengan menggunakan model korelasi berbasis zona, metode langkah demi langkah tipe 1. Dari hasil pemodelan diperoleh bahwa model terbaik untuk tarikan angkutan barang di Provinsi Kalimantan Timur adalah model yang menggunakan variabel-variabel bebas produksi telur dan ternak ayam, dengan koefisien determinasi sebesar 0,564.
\end{abstract}

Kata-kata kunci: tarikan pergerakan, angkutan barang, Matriks Asal dan Tujuan, zona eksternal

\section{PENDAHULUAN}

Indonesia memiliki letak geografis yang strategis, dengan jumlah penduduk dan tingkat pertumbuhan penduduk yang tinggi. Hal ini menyebabkan tingkat kebutuhan masyarakat akan barang meningkat hampir di seluruh daerah di Indonesia, mulai provinsi sampai ke kabupaten atau kota.

Selama ini pergerakan angkutan barang di Indonesia didominasi oleh angkutan jalan, yang mencapai sekitar 90\% dan bahkan cenderung dengan beban berlebih (Dinas Perhubungan Provinsi Kalimantan Timur, 2014). Besarnya pergerakan angkutan barang di Indo- 
nesia dapat direpresentasikan dengan Matriks Asal-Tujuan (MAT) atau dengan diagram garis keinginan (desire line).

Angkutan barang mempunyai peran penting sebagai pengangkutan kebutuhan ekonomi. Hasil survei Origin Destination (O-D) atau Survei Asal-Tujuan Nasional pada tahun 2001 dan tahun 2006 menyatakan bahwa hampir 83\% pergerakan barang di Indonesia terjadi di Pulau Jawa, 10\% di Pulau Sumatera, dan sisanya terdistribusi di bagian timur kepulauan Indonesia.

Kalimantan Timur merupakan provinsi dengan total luas wilayah terbesar ketiga di Indonesia setelah Papua dan Kalimantan Tengah. Luas wilayah Provinsi Kalimantan Timur sekitar 127.346,92 km² (Badan Pusat Statistik Kalimantan Timur, 2012). Hal ini menyebabkan tingkat pergerakan angkutan barang di Provinsi Kalimantan Timur cukup besar.

Pola pergerakan barang di Provinsi Kalimantan Timur dipengaruhi oleh potensi sumber daya alamnya. Kalimantan Timur memiliki sumber daya alam yang sangat melimpah, dengan yang utama adalah hasil tambang, seperti minyak, gas alam, dan batu bara. Sedangkan potensi sumber daya alam yang lain adalah hasil-hasil perkebunan, kehutanan, dan perikanan. Hasil perkebunan yang sangat menonjol di Provinsi Kalimantan Timur adalah hasil perkebunan kelapa sawit. Berdasarkan data O-D Nasional tahun 2011, total pergerakan barang di Provinsi Kalimantan Timur mencapai 12.373.676 ton per tahun. Sedangkan untuk total keseluruhan, termasuk pergerakan antarprovinsi, adalah sebesar 94.211.204 ton per tahun (Dinas Perhubungan Provinsi Kalimantan Timur, 2014).

Luas wilayah yang besar dan kondisi perbukitannya menimbulkan masalah transportasi barang di Provinsi Kalimantan Timur. Kurangnya perhatian yang diberikan terhadap transportasi barang dalam sistem transportasi di Indonesia, khususnya di Provinsi Kalimantan Timur, menyebabkan harga barang sangat bervariasi dari tingkat produsen hingga ke tingkat konsumen. Selain dipengaruhi oleh biaya produksi dan biaya penanganan, harga barang sangat dipengaruhi oleh biaya transportasi, baik saat barang bergerak maupun saat barang berpindah dari satu moda ke moda lainnya.

Pada penelitian ini dilakukan analisis model bangkitan dan tarikan pergerakan angkutan barang di Provinsi Kalimantan Timur. Analisis model ini diharapkan dapat menjadi acuan untuk perencanaan sistem transportasi, yang kemudian dapat dijadikan dasar rencana tata ruang wilayah Provinsi Kalimantan Timur, baik untuk jangka pendek maupun untuk jangka panjang, serta peningkatan kapasitas jalan lintas provinsi di Provinsi Kalimantan Timur.

\section{ANALISIS DAN PEMBAHASAN}

Model analisis yang digunakan pada penelitian ini adalah analisis tarikan pergerakan angkutan barang (model korelasi berbasis zona; metode langkah demi langkah tipe 1). Analisis ini dilakukan untuk mendapatkan hubungan linear antara jumlah pergerakan yang tertarik pada zona dan ciri sosio-ekonomi rata-rata pada setiap zona (Irianto, 2014). Tahapan pelaksanaan analisis adalah sebagai berikut: 
a) Pembagian zona dilakukan berdasarkan pengamatan pola pergerakan yang selama ini terjadi di lapangan (eksisting). Zona eksternal dibagi atas 3 zona, yaitu: (1) Zona Eksternal 1; pergerakan asal-tujuan Provinsi Kalimantan Utara, yaitu Malinau, Bulungan, Nunukan, dan Tarakan, (2) Zona Eksternal 2; pergerakan asal-tujuan Provinsi Kalimantan Selatan, yaitu Banjarmasin dan Kota Baru, dan (3) Zona Eksternal 3; pergerakan asal-tujuan Kota Palu, Kota Makassar, dan Kota Manado.

b) Pembagian zona internal: (1) Zona Internal 1: Kabupaten Paser, (2) Zona Internal 2: Kabupaten Kutai Kertanegara, (3) Zona Internal 3: Kabupaten Berau, (4) Zona Internal 4: Kabupaten Kutai Barat, (5) Zona Internal 5: Kabupaten Kutai Timur, (6) Zona Internal 6: Kabupaten Penajam Paser Utara, (7) Zona Internal 7: Kota Balikpapan, (8) Zona Internal 8: Kota Samarinda, dan (9) Zona Internal 9: Kota Bontang.

Matriks Asal Tujuan (MAT) yang digunakan merupakan MAT angkutan barang di Provinsi Kalimantan Timur hasil Survei ATTN (Asal Tujuan Transportasi Nasional) pada tahun 2011. Satuan yang digunakan pada data ini adalah ton/tahun. Adapun MAT tersebut dapat dilihat pada Tabel 1 .

Tabel 1 Matriks Asal Tujuan Angkutan Barang Provinsi Kalimantan Timur (ton/tahun)

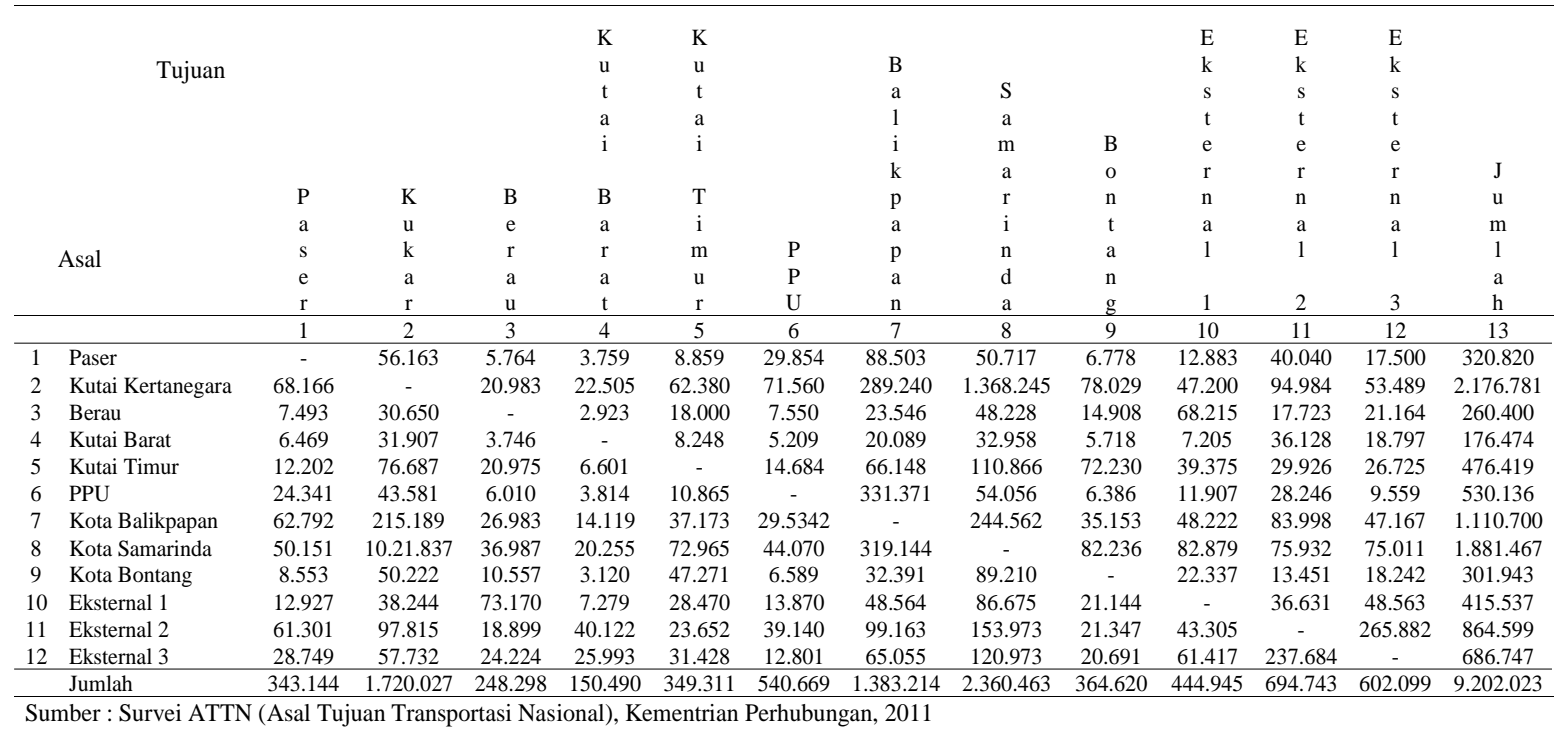

Data sosial ekonomi yang akan dianalisis merupakan data yang berasal dari buku Kalimantan Timur dalam Angka tahun 2012, yang diterbitkan oleh Badan Pusat Statistik (BPS) Provinsi Kalimantan Timur. Buku ini memuat data sosial-ekonomi pada tahun 2011. Keseluruhan data ini dipilih berdasarkan kemungkinan adanya pengaruh data tersebut terhadap bangkitan dan tarikan pergerakan angkutan barang serta ketersediaan data tersebut untuk dianalisis (Tamin, 2000). Data sosial ekonomi yang digunakan tersaji pada Tabel 2.

\section{Matriks Asal Tujuan Provinsi Kalimantan Timur}

Berdasarkan MAT yang telah disajikan, didapat besar tarikan pergerakan angkutan barang setelah dikonversi menjadi trip/tahun di Provinsi Kalimantan Timur. Besar tarikan pergerakan angkutan barang yang terjadi dapat dilihat pada Tabel 4. 
Tabel 2 Faktor Sosial Ekonomi Provinsi Kalimantan Timur (per tahun)

\begin{tabular}{|c|c|c|c|c|c|c|c|c|c|c|c|}
\hline No. & Zona & $\begin{array}{c}\text { PDRB } \\
\text { (Rupiah) }\end{array}$ & $\begin{array}{c}\text { Luas } \\
\text { Wilayah } \\
\text { (Ha) }\end{array}$ & $\begin{array}{c}\text { Banyak } \\
\text { Kecamatan }\end{array}$ & $\begin{array}{c}\text { Jumlah } \\
\text { Penduduk }\end{array}$ & $\begin{array}{l}\text { Produksi } \\
\text { Padi } \\
\text { Sawah } \\
\text { (ton) }\end{array}$ & $\begin{array}{c}\text { Produksi } \\
\text { Ubi } \\
\text { Jalar } \\
\text { (ton) }\end{array}$ & $\begin{array}{c}\text { Produksi } \\
\text { Kacang } \\
\text { Tanah } \\
\text { (ton) }\end{array}$ & $\begin{array}{c}\text { Produksi } \\
\text { Kacang } \\
\text { Hijau } \\
\text { (ton) }\end{array}$ & $\begin{array}{l}\text { Produksi } \\
\text { Kedelai } \\
\text { (ton) }\end{array}$ & $\begin{array}{c}\text { Produksi } \\
\text { Jagung } \\
\text { (ton) }\end{array}$ \\
\hline & & $\mathrm{X} 1$ & $\mathrm{X} 2$ & $\mathrm{X} 3$ & $\mathrm{X} 4$ & $\mathrm{X} 5$ & X6 & $\mathrm{X} 7$ & $\mathrm{X} 8$ & $\mathrm{X} 9$ & $\mathrm{X} 10$ \\
\hline 1 & Paser & 16.680 .292 & 1.119 .293 & 10 & 239.221 & 26.336 & 1446 & 112 & 54 & 155 & 529 \\
\hline 2 & Kutai Kertanegara & 51.946 .367 & 2.634 .895 & 18 & 650.908 & 198.023 & 6864 & 712 & 285 & 541 & 2.015 \\
\hline 3 & Berau & 9.607 .427 & 2.220 .033 & 13 & 186.003 & 16.559 & 1605 & 358 & 120 & 606 & 1.315 \\
\hline 4 & Kutai Barat & 8.083 .976 & 3.094 .560 & 21 & 171.474 & 5.423 & 2133 & 93 & 58 & 31 & 396 \\
\hline 5 & Kutai Timur & 44.900 .229 & 3.189 .649 & 18 & 265.521 & 19.854 & 1.732 & 202 & 68 & 299 & 1.117 \\
\hline 6 & Penajam Paser Utara & 2.615 .470 & 321.115 & 4 & 148.448 & 64.081 & 1.162 & 38 & 19 & 14 & 105 \\
\hline 7 & Balikpapan & 22.882 .880 & 56.128 & 5 & 579.137 & 997 & 165 & 6 & 0 & 0 & 665 \\
\hline 8 & Samarinda & 27.352 .115 & 71.783 & 10 & 755.628 & 15.012 & 317 & 15 & 4 & 6 & 50 \\
\hline 9 & Bontang & 9.543 .417 & 19.256 & 3 & 149.239 & 245 & 134 & 2 & 0 & 0 & 7 \\
\hline 10 & Eksternal 1 & 16.542 .821 & 6.756 .918 & 41 & 529.151 & 80.667 & 2.338 & 274 & 153 & 620 & 943 \\
\hline 11 & Eksternal 2 & 10.511 .542 & 949.540 & 25 & 931.977 & 65.663 & 5.063 & 1.172 & 314 & 2.514 & 20.491 \\
\hline 12 & Eksternal 3 & 89.260 .704 & 73.818 & 27 & 2.110 .004 & 15.489 & 1.700 & 345 & 34 & 0 & 5.969 \\
\hline
\end{tabular}

Tabel 3 Faktor Sosial Ekonomi Provinsi Kalimantan Timur (per tahun)

\begin{tabular}{|c|c|c|c|c|c|c|c|c|c|c|}
\hline No. Zona & $\begin{array}{l}\text { Produksi } \\
\text { Kelapa } \\
\text { Sawit } \\
\text { (ton) }\end{array}$ & $\begin{array}{l}\text { Produksi } \\
\text { Telur } \\
\text { (ton) }\end{array}$ & $\begin{array}{l}\text { Ternak } \\
\text { Ayam } \\
\text { (Ekor) }\end{array}$ & $\begin{array}{c}\text { Ternak } \\
\text { Kambing } \\
\text { (Ekor) }\end{array}$ & $\begin{array}{c}\text { Ternak } \\
\text { Sapi } \\
\text { (Ekor) }\end{array}$ & $\begin{array}{c}\text { Produksi } \\
\text { Perikanan } \\
\text { Laut } \\
\text { (ton) }\end{array}$ & $\begin{array}{l}\text { Produksi } \\
\text { Tambak } \\
\text { Air Payau } \\
\text { (ton) }\end{array}$ & $\begin{array}{c}\text { Jumlah } \\
\text { Rumah } \\
\text { Sakit }\end{array}$ & $\begin{array}{c}\text { Banyak } \\
\text { Kamar } \\
\text { Hotel } \\
\text { Berbintang }\end{array}$ & $\begin{array}{c}\text { Panjang } \\
\text { Jalan } \\
\text { Beraspal } \\
(\mathrm{km})\end{array}$ \\
\hline & $\mathrm{X} 11$ & $\mathrm{X} 12$ & $\mathrm{X} 13$ & $\mathrm{X} 14$ & $\mathrm{X} 15$ & $\mathrm{X} 16$ & $\mathrm{X} 17$ & $\mathrm{X} 18$ & $\mathrm{X} 19$ & $\mathrm{X} 20$ \\
\hline 1 Paser & 918.679 & 252 & 2.050 .000 & 4.847 & 12.189 & 10.009 & 3.669 & 1 & 465 & 223 \\
\hline 2 Kutai Kertanegara & 323.248 & 6.338 & 9.548 .925 & 6.828 & 23.464 & 31.463 & 7.672 & 2 & 784 & 361 \\
\hline 3 Berau & 275.951 & 106 & 1.748 .238 & 7.163 & 8.426 & 15.510 & 936 & 1 & 866 & 247 \\
\hline 4 Kutai Barat & 159.601 & 190 & 153,348 & 5,462 & 6.236 & 0 & 0 & 1 & 752 & 185 \\
\hline 5 Kutai Timur & 1.889 .599 & 0 & 1.821 .500 & 6.977 & 15.022 & 5.669 & 437 & 6 & 1.563 & 312 \\
\hline 6 Penajam Paser Utara & 513.640 & 407 & 35.191 & 4.982 & 10.440 & 4.447 & 5.091 & 2 & 179 & 59 \\
\hline 7 Balikpapan & 0 & 490 & 9.519 .240 & 2.087 & 1.652 & 6.386 & 248 & 12 & 2.549 & 46 \\
\hline 8 Samarinda & 1.064 & 1.661 & 8.640 .860 & 12.635 & 5.681 & 8.768 & 0 & 13 & 2.919 & 52 \\
\hline 9 Bontang & 0 & 41 & 1.781 .200 & 358 & 501 & 8.512 & 81 & 4 & 866 & 9 \\
\hline 10 Eksternal 1 & 389.764 & 464 & 3.133 .985 & 10.005 & 14.372 & 11.872 & 8.387 & 6 & 2.044 & 624 \\
\hline 11 Eksternal 2 & 0 & 0 & 14.492 .901 & 13.546 & 8.461 & 48.602 & 12.057 & 12 & 5.036 & 776 \\
\hline 12 Eksternal 3 & 0 & 2.056 & 4.795 .645 & 9.047 & 5.251 & 23.319 & 661 & 37 & 7.432 & 1.389 \\
\hline
\end{tabular}

Tabel 4 Besar Tarikan Pergerakan (trip/tahun) Berdasarkan MAT

\begin{tabular}{clc}
\hline No. & \multicolumn{1}{c}{ Zona } & $\begin{array}{c}\text { Tarikan Pergerakan } \\
\text { (Trip/Tahun) }\end{array}$ \\
\hline 1 & Paser & 114.381 \\
2 & Kutai Kertanegara & 573.342 \\
3 & Berau & 82.766 \\
4 & Kutai Barat & 50.163 \\
5 & Kutai Timur & 116.437 \\
6 & Penajam Paser Utara (PPU) & 180.223 \\
7 & Balikpapan & 461.071 \\
8 & Samarinda & 786.821 \\
9 & Bontang & 121.540 \\
10 & Zona Eksternal 1 & 148.315 \\
11 & Zona Eksternal 2 & 231.581 \\
12 & Zona Eksternal 3 & 200.700 \\
\hline & Jumlah & 3.067 .340 \\
\hline & Rata-Rata & 255.612 \\
\hline
\end{tabular}

\section{Analisis Model Pergerakan Tarikan}

Analisis regresi linier berganda digunakan untuk meramalkan suatu variabel terikat tarikan (Y) berdasarkan 20 variabel bebas yang ada. Untuk mendapatkan model yang paling 
sesuai menggambarkan pengaruh suatu atau beberapa variabel bebas terhadap variabel terikat digunakan analisis regresi berganda (Usman dan Akbar, 2008). Dengan metode analisis langkah demi langkah dicari model terbaik yang paling tepat dalam mencerminkan realita yang ada (Misbahudin dan Hasan, 2013). Variabel bebas yang selanjutnya akan dianalisis regresi linier berganda adalah: (1) PDRB, (2) Luas Wilayah, (3) Jumlah Penduduk, (4) Produksi Kelapa Sawit, (5) Produksi Telur, (6) Ternak Ayam, dan (7) Ternak Kambing.

Dari 7 variabel ini kemudian dilakukan analisis regresi linier berganda menjadi beberapa tahap. Dalam setiap tahap, variabel yang tidak signifikan dihilangkan, kemudian didapatkan persamaan yang baru. Dari proses ini diperoleh model terbaik yang mendekati kondisi nyata di lapangan.

Berdasarkan hasil analisis regresi linier berganda yang dilakukan, dapat dilakukan proses penentuan model dengan metode langkah demi langkah tipe 1 sesuai dengan prosedur yang ada (Riduwan dan Akdon. 2006). Hasil pemodelan dari tarikan pergerakan dapat dilihat pada Tabel 5 .

Tabel 5 Hasil Pemodelan Tarikan Pergerakan Angkutan Barang

\begin{tabular}{|c|c|c|c|c|c|c|c|c|c|c|}
\hline No. & Peubah & $\begin{array}{c}\text { Tanda } \\
\text { yang } \\
\text { Diharapkan }\end{array}$ & $\begin{array}{c}\text { Parameter } \\
\text { Model }\end{array}$ & \multicolumn{7}{|c|}{ Tahap } \\
\hline 1 & Inersep & $+/-$ & $\mathrm{C}$ & $128.081,978$ & $178.842,185$ & $161.492,481$ & $99.528,859$ & $101.496,536$ & $86.023,453$ & $10.211,552$ \\
\hline 3 & Luas Wilayah & + & $\mathrm{X}_{2}$ & $-0,041$ & $-0,022$ & $-0,027$ & - & - & - & - \\
\hline 4 & Jumlah Penduduk & + & $\mathrm{X}_{4}$ & $-0,607$ & $-0,196$ & $-0,089$ & $-0,064$ & $-0,055$ & - & - \\
\hline 5 & Produksi Kelapa Sawit & + & $\mathrm{X}_{11}$ & 14,937 & $-0,073$ & - & - & - & - & - \\
\hline 6 & Produksi Telur & + & $\mathrm{X}_{12}$ & 14,937 & 44,053 & 58,438 & 54,357 & 55,673 & 52,348 & - \\
\hline & $\mathrm{R}$ & & & 0,855 & 0,797 & 0,792 & 0,760 & 0,760 & 0,751 & 0,645 \\
\hline & $\mathrm{R}^{2}$ & & & 0,731 & 0,635 & 0,628 & 0,578 & 0,578 & 0,564 & 0,417 \\
\hline & F-Stat & & & 1,550 & 1,455 & 2,023 & 2,399 & 3,653 & 5,826 & 7,142 \\
\hline
\end{tabular}

Dalam memilih model terbaik, digunakan kriteria seluruh parameter regresi bertanda positif, sehingga hasil yang diharapkan mendekati kondisi nyata (Ortuzar dan Willumsen, 1994). Pada studi ini, model terbaik yang terpilih dan yang mencerminkan realita yang ada adalah:

$$
Y=86.023,453+52,348 X_{12}+0,024 X_{13}
$$

Dari pemodelan yang dilakukan diketahui bahwa faktor-faktor yang memengaruhi tarikan pergerakan angkutan barang $(\mathrm{Y})$ adalah Produksi Telur $\left(\mathrm{X}_{12}\right)$ dan Ternak Ayam $\left(\mathrm{X}_{13}\right)$ terhadap besarnya tarikan perjalanan (Y). Keeratan hubungan antara variabel ditunjukkan oleh nilai koefisien korelasi (R) sebesar 0,751. Sedangkan kuat hubungan yang ditunjukkan oleh variabel bebas terhadap variabel terikat dalam model yang terbentuk dapat dilihat dari koefisien determinasi $\left(\mathrm{R}^{2}\right)$, yaitu sebesar 0,564 .

\section{Uji Verifikasi untuk Model Tarikan}

Selanjutnya dihitung nilai Y berdasarkan nilai masing-masing variabel bebas tersebut. Nilai Y inilah yang merupakan besar tarikan pergerakan angkutan barang berdasarkan 
model yang selanjutnya dibandingkan dengan besar tarikan pergerakan angkutan barang berdasarkan MAT. Tujuannya adalah sebagai verifikasi model tarikan yang diperoleh terhadap kondisi nyata yang ada di lapangan (Tamin, 2000). Besar tarikan berdasarkan model dan MAT dapat dilihat pada Tabel 6.

Tabel 6 Besar Tarikan Pergerakan Berdasarkan Model dan MAT

\begin{tabular}{clccc}
\hline No. & Zona & $\begin{array}{c}\text { Model } \\
\text { (Trip/Tahun) }\end{array}$ & $\begin{array}{c}\text { MAT } \\
\text { (Trip/Tahun) }\end{array}$ & $\begin{array}{c}\text { Selisih } \\
\text { (Trip/Tahun) }\end{array}$ \\
\hline 1. & Paser & 148.415 & 114.381 & 34.034 \\
2. & Kutai Kertanegara & 646.979 & 573.342 & 73.637 \\
3. & Berau & 133.530 & 82.766 & 50.764 \\
4. & Kutai Barat & 99.649 & 50.163 & 49.486 \\
5. & Kutai Timur & 129.739 & 116.437 & 13.302 \\
6. & Penajam Paser Utara & 108.174 & 180.223 & 72.049 \\
7. & Balikpapan & 340.136 & 461.071 & 120.935 \\
8. & Samarinda & 380.354 & 786.821 & 406.467 \\
9. & Bontang & 130.919 & 121.540 & 9.379 \\
10. & Eksternal 1 & 185.529 & 148.315 & 37.214 \\
11. & Ekternal 2 & 433.853 & 231.581 & 202.272 \\
12. & Eksternal 3 & 308.747 & 200.700 & 108.047 \\
\hline
\end{tabular}

\section{Analisis Pertumbuhan Pergerakan Model}

Berdasarkan model yang telah didapat untuk bangkitan dan tarikan, langkah selanjutnya adalah memprediksikan besar pergerakan pada masa yang akan datang. Besarnya laju pertumbuhan pergerakan kendaraan angkutan barang ditentukan berdasarkan Manual Perkerasan Jalan Nomor 04/SE/Db/2017, yaitu sebesar 5\% per tahun (Direktorat Jenderal Bina Marga, 2017). Proyeksi tarikan menggunakan nilai variabel bebas dengan nilai pertumbuhan pergerakan sebesar 5\% tersebut. Hasil perhitungan proyeksi tarikan pergerakan dapat dilihat pada Tabel 7.

Tabel 7 Perhitungan Proyeksi Tarikan Pergerakan Angkutan Barang

\begin{tabular}{|c|c|c|c|c|c|}
\hline \multirow{2}{*}{ No. } & \multirow{2}{*}{ Zona } & \multicolumn{4}{|c|}{ Model $Y=86.023,453+52,348 X_{12}+0,024 X_{13}$} \\
\hline & & 2011 & 2012 & 2017 & 2022 \\
\hline 1 & Paser & 148.415 & 155.836 & 198.890 & 253.840 \\
\hline 2 & Kutai Kertanegara & 646.979 & 679.328 & 867.014 & 1.106 .554 \\
\hline 3 & Berau & 133.530 & 140.207 & 178.943 & 228.382 \\
\hline 4 & Kutai Barat & 99.649 & 104.632 & 133.540 & 170.434 \\
\hline 5 & Kutai Timur & 129.739 & 136.226 & 173.863 & 221.898 \\
\hline 6 & Penajam Paser Utara & 108.174 & 113.583 & 144.964 & 185.014 \\
\hline 7 & Balikpapan & 340.136 & 357.143 & 455.815 & 581.748 \\
\hline 8 & Samarinda & 380.354 & 399.373 & 509.711 & 650.535 \\
\hline 9 & Bontang & 130.919 & 137.465 & 175.444 & 223.916 \\
\hline 10 & Eksternal 1 & 185.529 & 194.806 & 248.627 & 317.318 \\
\hline 11 & Ekternal 2 & 433.853 & 455.546 & 581.405 & 742.036 \\
\hline 12 & Eksternal 3 & 308.747 & 324.185 & 413.751 & 528.062 \\
\hline
\end{tabular}




\section{KESIMPULAN}

Berdasarkan hasil analisis data pada penelitian ini dapat ditarik beberapa kesimpulan bahwa model terbaik untuk tarikan angkutan barang di Provinsi Kalimantan Timur adalah model yang menggunakan variabel-variabel bebas Produksi Telur dan Ternak Ayam. Model, dengan koefisien determinasi sebesar ini mempunyai koefisien determinasi $\left(\mathrm{R}^{2}\right)$ sebesar 0,564 .

Dengan menggunakan model-model tarikan tersebut dihitung jumlah tarikan perjalanan angkutan barang yang ditarik ke dalam Provinsi Kalimantan Timur pada tahun 2017. Hasilnya berturut-turut adalah untuk Zona Paser sebesar 198.890 trip/tahun, Zona Kutai Kertanegara sebesar 867.014 trip/tahun, Zona Berau sebesar 178.943 trip/tahun, Zona Kutai Barat sebesar 133.540 trip/tahun, Zona Kutai Timur sebesar 173.863 trip/tahun, Zona Penajam Paser Utara sebesar 144.964 trip/tahun, Zona Balikpapan sebesar 455.815 trip/tahun, Zona Samarinda sebesar 509.711 trip/tahun, Zona Bontang sebesar 175.444 trip/tahun, Zona Eksternal 1 sebesar 248.627 trip/tahun, Zona Eksternal 2 sebesar 581.405 trip/tahun, dan Zona Eksternal 3 sebesar 413.751 trip/tahun.

Berdasarkan model tarikan dilakukan estimasi jumlah tarikan perjalanan angkutan barang untuk tahun 2022. Hasilnya untuk Zona Paser sebesar 253.840 trip/tahun, Zona Kutai Kertanegara sebesar 1.106.554 trip/tahun, Zona Berau sebesar 228.382 trip/tahun, Zona Kutai Barat sebesar 170.434 trip/tahun, Zona Kutai Timur sebesar 221.898 trip/tahun, Zona Penajam Paser Utara sebesar 185.014 trip/tahun, Zona Balikpapan sebesar 581.748 trip/tahun, Zona Samarinda sebesar 650.535 trip/tahun, Zona Bontang sebesar 223.916 trip/tahun, Zona Eksternal 1 sebesar 317.318 trip/tahun, Zona Eksternal 2 sebesar 742.036 trip/tahun, dan Zona Eksternal 3 sebesar 528.062 trip/tahun.

\section{DAFTAR PUSTAKA}

Badan Pusat Statistik Kalimantan Timur. 2012. Kalimantan Timur dalam Angka 2012. Samarinda.

Dinas Perhubungan Provinsi Kalimantan Timur. 2014. Studi Master Plan Jaringan Kereta Api (KA) Provinsi Kalimantan Timur. Samarinda.

Direktorat Jenderal Bina Marga. 2017. Manual Perkerasan Jalan (Revisi Juni 2017), Nomor 04/SE/Db/2017. Kementerian Pekerjaan Umum dan Perumahan Rakyat. Jakarta.

Irianto, A. 2014. Statistik Konsep Dasar, Aplikasi, dan Pengembangannya. Jakarta: Kencana Prenadamedia Group.

Misbahudin dan Hasan, I. 2013. Analisis Data Penelitian dengan Statistik. Jakarta: Bumi Aksara.

Ortuzar J.D. dan Willumsen, L.G. 1994. Modelling Transport. New York, NY: John Wiley $\&$ Sons. 
Riduwan dan Akdon. 2006. Rumus dan Data dalam Aplikasi Statistika. Bandung: Alfabeta. Tamin, O.Z. 2000. Perencanaan dan Permodelan Transportasi. Bandung: Penerbit ITB. Usman, H. dan Akbar, P. 2008. Pengantar Statistika. Jakarta: Bumi Aksara. 